\title{
COMPARATIVE ANALYSIS OF THE PROFITABILITY OF RICE PRODUCTION SYSTEMS IN KWARA STATE, NIGERIA
}

\author{
Oloyede, W.O., Muhammad-Lawal, A., Amolegbe, K. B., Olaghere, I.L. and Joseph, I.A \\ Department of Agricultural Economics and Farm Management, P.M.B 1515, University of Ilorin, \\ Ilorin, Nigeria \\ *Corresponding author's email: olaide.oloyede1@gmail.com
}

\begin{abstract}
This study describes the socioeconomic characteristics of rice farmers, identifies the production system used by the farmers, compares the profitability of rice production systems, identifies the factors influencing the choice of production systems among the farmers as well as the constraints to rice production systems. A three-stage random sampling procedure was used to select 120 rice farmers on whom a set structured questionnaire was administered. Data was analysed using descriptive statistics and multinomial logistic regression model. Results show that $48.3 \%, 35 \%$ and $16.7 \%$ of the farmers cultivate rice using the upland, lowland and the combined production systems respectively. The findings also reveal variability in yield, profit and income across the rice production systems. The gross margins for lowland, upland and combined rice production systems were $\$ 65,735.73, A 67,900.89$ and $\$ 78,015.57$ per hectare respectively. The factors that influenced the choice of upland production system relative to combined production system were age, household size, farming years and extension visits while the factors that influenced the choice for combined rice production system relative to lowland rice production system was income. Inadequate finance to purchase inputs, problem of pests and diseases, and unfavorable climatic conditions are the constraints faced by rice farmers in the upland, lowland and combined production systems. The combined production systems had the highest return per hectare. Therefore, the study recommends that farmers should be encouraged to choose the combined rice production system for optimum profitability of rice production.
\end{abstract}

Keywords: Production systems, Profitability, Determinants, Gross margin, Upland Rice, Lowland Rice 


\section{INTRODUCTION}

Although Nigeria is heavily dependent on oil, agriculture contributes significantly to the nation's economy. The Gross Domestic Product (GDP) from Agriculture in Nigeria increased to 3857705.59 NGN Million in the second quarter of 2019 from 3597916.08 NGN Million in the first quarter of 2019 (National Bureau of Statistics, 2019). The majority of the Nigerian populace obtain their means of livelihood from agriculture, providing raw materials for the manufacturing sector and the generation of foreign exchange (Odoemenem \& Inakwu, 2011).

Rice is an increasingly important crop moving in recent times from a ceremonial food to a staple food in many homes. Rice consumption in Nigeria has immensely risen at about $5 \%$ per annum owing to changing consumer choices (Ishaku, 2013). Rice production is generally small-scale in Nigeria. Local production has not met the demand for its teeming population. This, however, led to a demand/supply gap causing a shift in local production to meet the demand for its teeming population. Relying on the import of expensive food on global markets not only stimulates domestic inflation, but also hurts Nigerian farmers, displacing local production and fueling rising unemployment (Federal Ministry of Agriculture and Rural Development, 2012).

In 2016, the price of rice doubled over 2015 prices, owing largely to foreign exchange rates and fluctuations in government policy on rice importation. Yet, domestic demand for rice is still high. United States Department of Agriculture (USDA) 2014/2015 estimates show that of 6.4 million MT domestic demand of milled rice in Nigeria, only 2.84 million MT was produced locally (Live Rice Index [LRI], 2016). In Nigeria, it has been established that rice thrives in four main ecologies. However, it is grown in all regions of the country (Nosiru, Rahji, Ikpi \& Adenegan, 2014). The main production ecologies for rice in Nigeria include the rain fed lowland, rain fed upland, irrigated lowland and mangrove swamp ecosystem (ATA, 2010).

Farmers grow rice using either the lowland, upland or combined rice production system based on the expected output and returns from the choice of the rice production system. However, in Subsaharan Africa (SSA), the increase in rice production has been due to an expansion of the area under cultivation rather than to an increase in yield (Stryker, 2010). Therefore, a sustainable increase in the production of rice involves the mechanization into an ecosystems approach to achieve higher productivity, profitability and resource use efficiency, while protecting and even enhancing the environment.

Rain fed lowland rice system is the most prominent rice production system in Nigeria. It is reported that $53 \%$ of Nigerian rice area is under rain fed lowland rice cultivation which contributes close to half of the national rice production (ATA, 2010). There are two subtypes which are Shallow Fadama and Deep Fadama or deep inlands valleys or so-called wetlands. In Deep Fadama, the land is 
flooded all the time or during the major part of the cropping season. Shallow Fadamas are seldom flooded.

The Upland Rice System refers to rice grown on both flat and sloping fields that are not bunded, that are prepared and seeded under dry conditions, and that depend on rainfall for moisture (IRRI, 1975). The seeds are sown directly to the field. According to FAO (2009), the field is better cleared and filled at the beginning of the rainy season so that the soil holds the water. It further recommended that sowing should be done using selected seeds that were disinfected and farmers are advised to sow in rows. Two types of Upland Rice Systems are found in Nigeria. These are Rain fed Upland and Irrigated Upland.

The Rain fed Upland Rice System is the most dominant upland rice system in Nigeria. It is found in all agro-ecological zones. The crop depends entirely on rainfall. Heavy rainfall can lead to soil erosion, leaching of plant nutrients and possibly flooding. The risk of poor grain filling due to drought is also high. In irrigated Upland Rice System where the length of growing period is short, some form of supplementary irrigation may be required to improve drought conditions during critical stages of growth in the rice crop.

The mangrove swamp rice production system is found on coastal areas where the ocean floods the land at high tide and drains away at low tide. Most mangrove swamps have salt free growing period during the rainy season when freshwater flooding washes the land and displaces tidal flows. Consequently, the rice growing period is directly related to distance from the ocean, and varies from under four months in the nearest estuaries to more than six months in the more distant ones. Soils are generally more fertile than in other ecologies since they benefit from regular deposit of silt during annual flooding. However, the soils are also characterized by high salinity and sulphate acidity. This production system can be found in the Niger-Delta, the deep flooded areas of Lagos and Calabar. While the system has great potential for rice cultivation in Nigeria, high labour costs associated with clearing and potential negative environmental impacts from oil exploration activities pose major constraints to further expansion of the area (Eze, 2014).

Nigeria is ecologically endowed to achieve self-sufficiency in rice production with potential land area for rice production of between 4.6 million and 4.9 million ha (FMARD, 2012). However, in spite of the immense untapped potential of rice production in Nigeria, only 1.8 million ha of Nigeria's total land mass suitable for rice production is cropped to rice (Coalition for African Rice Development [CARD], 2009). Regardless of the very favourable ecologies for rice production in Nigeria, rice production remains low. Oyinbo, Damisa and Rekwot (2013) reported that less than $10 \%$ of the potential 3.4 million hectares are currently irrigated. The choice of a balanced approach to the use of rice production systems presents an opportunity to be exploited (Macauley, 2015). Estimates 
indicate that over 90 percent of domestic rice production comes from resource-poor and weakly organized smallholders (USAID 2009; Cadoni and Angelucci, 2013). These smallholders apply a low-input strategy to agriculture, with minimum input requirements and low output (International Fund for Agricultural Development [IFAD], 2009). The livelihood of these smallholder farmers have been constrained by a host of challenges: low productivity; paucity of opportunities for value addition; limited access to productive assets and inputs; inadequate support services (extension and research); inadequate market and rural infrastructure; post-harvest losses and a constrained enabling environment (IFAD, 2012). More so, a huge proportion of domestic rice in Nigeria is not tailored to meet market needs. This has also limited the market share of the domestic rice producers. In 2016, the price of rice doubled over 2015 prices, due to foreign exchange rates and changes in government policy on the importation of rice. United States Department of Agriculture (USDA) 2014/2015 estimates revealed that of 6.4 million MT domestic demand of milled rice in Nigeria, only 2.84 million MT was produced locally (Live Rice Index [LRI], 2016). Presently in 2019, the prices of rice have yet doubled again despite considerable improvements in local production indicating that a demand-supply gap still exists. Local rice is majorly produced by small-scale resource poor farmers that use traditional technology for their production activities. Despite the favorable ecological conditions in Nigeria, local rice producers are yet to explore this advantage for profitability purposes. Although, rice production is a profitable business, there is need to study the potential of the production systems under which rice farmers carry out their production activities. Nneka, Donatus \& Steve (2019) carried out a study on the profitability of rice production in different production systems in Ebonyi State, Nigeria and concluded that returns to farmers using the swamp production system was profitable, followed by lowland and upland rice production systems. The choice of balanced approach to the use of rice production systems presents an opportunity to be exploited (Macauley, 2015). Therefore, this paper seeks to carry out a comparative analysis of the profitability of various rice production systems used by rice farmers in Kwara State, Nigeria.

\section{METHODOLOGY}

\section{Study Area}

This study was carried out in Edu and Patigi LGA in Kwara State, Nigeria. Kwara State is in North Central geopolitical zone of Nigeria, commonly referred to as the Middle Belt. Kwara State is situated between latitudes $7^{\circ} 45^{\prime}$ and $9^{\circ} 30^{\prime}$ North and longitudes $2^{\circ} 30^{\prime}$ and $6^{\circ} 35^{\prime}$ East, with Niger State in the north, Kogi State in the east, Oyo, Ekiti and Osun States in the south and an international boundary with the Republic of Benin in the west. The state covers a land area of 36,825 square kilometers. 
Agriculture is the mainstay of the economy of the state. The state has a population of about 2.37 million people (NPC, 2006). The target population for this study are rice farmers that produce lowland and upland rice in the study area. The state is made up of 16 Local Government Areas. Edu and Patigi LGAs were purposively selected because they are representative zone for rice production in Kwara State due to their proximity to Niger River where they practice rice cultivation and hence high concentration of rice farmers in the area. Patigi is a town in Kwara state along the banks of the Niger River. The headquarters is situated at Kwara North. It has a total land area of 2,743 square kilometers and a population of about 110,852 (NPC, 2006). The climate is characterized by rainy and dry season. The rainy season begins from early April and ends in October and the dry season begins at the end of November to March (NSG, 2006). The LGA is one of the largest Fadama lowlands in the state with River Niger as the primary source of water. The residents are majorly fishermen and lowland and upland rice farmers, they also cultivate other crops such as millet, guinea corn and melon. Edu is also a LGA in Kwara State with its headquarters in the town of Lafiagi. It has a land area of 2,542square kilometers and a population of 201,469 (NPC, 2009). They are also along the banks of River Niger, which made fishing their major occupation as well as rice production.

\section{Sampling Technique and Sampling Size}

A three-stage sampling procedure was employed in selecting the rice farmers for the study from whom data were collected with the use of a semi-structured questionnaire. The first stage involved a purposive selection of Edu and Patigi Local Government Areas being major rice producing areas in Kwara State. The second stage was a purposive selection of four communities that are prominent in rice farming each from the selected two Local Governments. The third stage involved the random selection of 10 percent of registered rice farmers in the eight (8) selected communities makito give a total of 120 rice farmers. 
Table 1: Sample Distribution of Study Area.

\begin{tabular}{ccc}
\hline LGAs & Names of communities & $\begin{array}{c}\text { Number of Rice Farming } \\
\text { Household interviewed }\end{array}$ \\
\hline \multirow{2}{*}{ EDU } & 1. Tsaragi & 20 \\
& 2. Edogi & 14 \\
& 3. Lade & 16 \\
& 4. Kpada & 11 \\
& 1. Patigi & 19 \\
PATIGI & 2. Tsonga & 18 \\
& 3. Kaworo & 12 \\
& 4. Cheukogi & 11 \\
2 & 8 & 120 \\
\hline
\end{tabular}

Source: Field Survey, 2018

Primary data were used for the study. The data were collected with the use of well-structured questionnaires, consisting of both closed and open-ended questions. The analytical tools used to achieve the objectives of this study were descriptive statistics, gross margin analysis, multinomial logistic regression model and Likert-type scale. Descriptive statistics such as frequency, means and percentages were used to determine the rice production systems employed by rice farmers. The socio-economic characteristics of the farmers, such as age, gender, marital status, education, household size and farming experience, were also described with the descriptive statistics. Gross margin analysis was used to estimate the profitability of the rice production systems. Gross margin is the difference between the gross farm income (GFI) and the total variable cost (TVC), that is;

$$
\mathrm{GM}=\mathrm{GFI}-\mathrm{TVC} \text {. }
$$

Where: $\mathrm{GM}=$ Gross Margin (Naira/hectare)

GFI = Gross Farm Income (Naira/hectare)

TVC = Total Variable Cost (Naira/hectare)

Multinomial logistic regression model was used to determine the factors that influenced the choice of the production systems employed by rice farmers under lowland and upland and the combination of both lowland and upland rice production systems. Fakayode (2009) used the multinomial logit regression model to determine the factors that influence the use of either lowland or upland rice production system or the combined rice production system. The model was chosen based on survey results that revealed that farmers' rice production (dependent variable) was found to be a 
categorical variable which can take three (3) categories or levels. The multinomial logit model expressed the probability of a rice farmer being in a particular category. These categories were assigned numbers 1,2 and 3. Category 3 was used to indicate the combined (lowland and upland rice) producer group; 1 for only lowland rice producer group and 2 was used to indicate the upland rice producer group. The combined lowland and upland rice producer group was taken as the reference group. The multinomial logit model was therefore used to identify the factors that make farmers belong to categories 2 (upland rice producer group) and 3 (combined (lowland and upland rice producer group) instead of 1 (lowland rice producer group).

In the multinomial logit model, you estimate a set of coefficients, $\beta(1), \beta(2)$, and $\beta(3)$, corresponding to each outcome:

$$
\begin{aligned}
& \operatorname{Pr}(y=1)=\frac{e^{X \beta^{(1)}}}{e^{X \beta^{(1)}}+e^{X \beta^{(2)}}+e^{X \beta^{(3)}}} \\
& \operatorname{Pr}(y=2)=\frac{e^{X \beta^{(2)}}}{e^{X \beta^{(1)}}+e^{X \beta^{(2)}}+e^{X \beta^{(3)}}} \\
& \operatorname{Pr}(y=3)=\frac{e^{X \beta^{(3)}}}{e^{X \beta^{(1)}}+e^{X \beta^{(2)}}+e^{X \beta^{(3)}}}
\end{aligned}
$$

The model, however, is unidentified in the sense that there is more than one solution to $\beta(1), \beta(2)$, and $\beta(3)$ that leads to the same probabilities for $y=1, y=2$, and $y=3$. To identify the model, you arbitrarily set one of $\beta(1), \beta(2)$, or $\beta(3)$ to 0 -it does not matter which. That is, if you arbitrarily set $\beta(1)=0$, the remaining coefficients $\beta(2)$ and $\beta(3)$ will measure the change relative to the $y=1$ group. If you instead set $\beta(2)=0$, the remaining coefficients $\beta(1)$ and $\beta(3)$ will measure the change relative to the $y=2$ group. The coefficients will differ because they have different interpretations, but the predicted probabilities for $y=1,2$, and 3 will still be the same. Thus either parameterization will be a solution to the same underlying model.

$$
p_{i j}=\operatorname{Pr}\left(y_{j}=i\right)=\left\{\begin{array}{l}
\frac{1}{1+\sum_{m=2}^{k} \exp \left(\mathbf{x}_{j} \boldsymbol{\beta}_{m}\right)}, \text { if } i=1 \\
\frac{\exp \left(\mathbf{x}_{j} \boldsymbol{\beta}_{i}\right)}{1+\sum_{m=2}^{k} \exp \left(\mathbf{x}_{j} \boldsymbol{\beta}_{m}\right)}, \text { if } i>1
\end{array}\right.
$$


where $\mathbf{x} j$ is the row vector of observed values of the independent variables for the $j$ th observation and $\beta m$ is the coefficient vector for outcome $m$. The log pseudolikelihood is

$$
\ln L=\sum_{j} w_{j} \sum_{i=1}^{k} I_{i}\left(y_{j}\right) \ln p_{i k}
$$

The independent variables used include age, education, household size, farming years, extension visits, training (dummy variable) and total farm income.

The explicit form of the functions is specified as follows:

$P_{i j}=\beta_{0}+\beta_{1} X_{1}+\beta_{2} X_{2}+\beta_{3} X_{3}+\beta_{4} X_{4}+\beta_{5} X_{5}+\beta_{6} X_{6}+\mathrm{e}$

Where:

$P_{i j}=$ probability of being in each of the groups 1,2 and 3.

$\beta_{0}=$ Intercept

$\beta_{1}-\beta_{7}=$ Coefficient of the independent variables $X_{1}-X_{7}$

$X_{1}=$ Age of farmers in years

$X_{2}=$ Education

$X_{3}=$ Household Size

$X_{4}=$ Farming years

$X_{5}=$ Extension visits

$X_{6}=$ Training in chosen production system ( 1 if rice farmer has received training; 0 otherwise)

$X_{7}$ Total income from the chosen production system

$\mathrm{e}=$ error term

Likert-type scale was used to identify the constraints associated with lowland and upland production systems in the study area. This method was used to analyze, identify and rank the constraints limiting rice production activity of lowland and upland rice farmers in the area. A Likert scale is a psychometric scale commonly involved in research based on survey questionnaires. The range of Likert-type scale captures the intensity of their feelings for a given item (Likert, 1932). After the data was collected with the aid of questionnaires, each Likert scale item was analyzed separately and summed up to create a score for a group of items. It was measured on a five-point scale. The attributes were drawn and their scale values were specified as follows: 


\section{Level of Severity}

Very severe

Severe

Mildly severe

Not severe

Not a problem at all

\section{Score}

5

4

3

2

1

The weighted score is as follows:

$X_{W}=5\left(F_{5}\right)+4\left(F_{4}\right)+3\left(F_{3}\right)+2\left(F_{2}\right)+1\left(F_{1}\right)$

Where; $X_{W}=$ weighted score

$5-1=$ rating scale of extremely serious problem to not serious at all

$F_{5}-F_{1}=$ frequency of the respondents in each scale

The values of the weighted score will be used to rank the constraints encountered in each production system

Mean Score $=\frac{\text { total score of each problem }}{\text { total number of respondents }}$

The values numbered $5-1$ was added to give a total of 15 and a mean of 3 i.e. $\frac{5+4+3+2+1}{5}$

Any constraint with a mean score greater or equal to 3 was regarded as being serious and a mean less than 3 was considered not serious or mild.

\section{RESULTS AND DISCUSSION}

\section{Socio-economic Characteristics of the Rice Farmers}

This section describes the socio-economic characteristics of lowland and upland rice farmers in the study area. The results indicate that diverse characteristics are possessed by the farmers and are discussed accordingly. Table 2 shows that $92.5 \%$ of the respondents were male, while $7.5 \%$ were female. The analysis revealed that males are more involved in rice farming than females. A similar result of no female or relatively small number of females indulging in rice farming have been reported in past studies (Okoruwa et al., 2009). This finding may be attributed to lack of access to productive resources. This may be connected with the tedious nature of the enterprise. Generally, females may not have free access to land which can hinder their involvement in rice farming. The mean age of the rice farmers was found to be 45 years. About $7.5 \%$ of the respondents were between $21-30$ years, $25 \%$ within $31-40$ years, $36.7 \%$ within $41-50$ years, $18.3 \%$ within $51-60$ years, $10.8 \%$ within $61-70$ years and $1.7 \%$ within $70-80$ years. About $70 \%$ of the respondents were found to belong to the active agricultural age group within 21-50 years showing that farmers are still actively involved in rice production. Young farmers tend to be stronger, more capable of making 
good production decisions and have more potential for greater productivity than old farmers, hence are likely to be more efficient in the use of production inputs than older farmers (Adeola, 2010).

Table 2. Socio-economic Characteristics of Rice Farmers in Kwara State

\begin{tabular}{|c|c|c|}
\hline Variables & Frequency $(n=120)$ & Percentage \\
\hline \multicolumn{3}{|l|}{ Sex } \\
\hline Male & 111 & 92.5 \\
\hline Female & 9 & 7.5 \\
\hline \multicolumn{3}{|l|}{ Age (years) } \\
\hline $21-30$ & 9 & 7.5 \\
\hline $31-40$ & 30 & 25.0 \\
\hline $41-50$ & 44 & 36.7 \\
\hline $51-60$ & 22 & 18.3 \\
\hline $61-70$ & 13 & 10.8 \\
\hline $70-80$ & 2 & 1.7 \\
\hline \multicolumn{3}{|l|}{ Marital Status } \\
\hline Single & 13 & 10.8 \\
\hline Married & 93 & 77.5 \\
\hline Divorced & 2 & 1.7 \\
\hline Widowed & 12 & 10.0 \\
\hline \multicolumn{3}{|l|}{ Educational Qualification } \\
\hline No Formal Education & 15 & 12.5 \\
\hline Quranic & 5 & 4.2 \\
\hline Adult Education & 11 & 9.2 \\
\hline Primary & 28 & 23.3 \\
\hline Secondary & 45 & 37.5 \\
\hline Tertiary & 16 & 13.3 \\
\hline \multicolumn{3}{|l|}{ Household Size } \\
\hline $1-5$ & 36 & 30.0 \\
\hline $6-10$ & 64 & 53.3 \\
\hline $11-15$ & 15 & 12.5 \\
\hline $16-20$ & 5 & 4.2 \\
\hline \multicolumn{3}{|l|}{ Farming Experience } \\
\hline $1-10$ & 46 & 38.3 \\
\hline $11-20$ & 47 & 39.2 \\
\hline $21-30$ & 23 & 19.2 \\
\hline $31-40$ & 4 & 3.3 \\
\hline \multicolumn{3}{|l|}{ Membership of Cooperatives } \\
\hline Yes & 28 & 23.3 \\
\hline No & 92 & 76.7 \\
\hline
\end{tabular}

Source: Field Survey, 2018 
The involvement of the respondents between $61-80$ years was about $12.5 \%$, implying that the older farmers are less actively involved in farming. The minimum age of the respondents was 26 years while the maximum age was 72 years. Table 2 also shows that about $10.8 \%$ of the respondents were single, $77.5 \%$ were married, $1.7 \%$ were divorced and $10 \%$ were widowed. The majority of the farmers were married which agrees with the study carried out by Onumadu and Osahon (2014). The essence of marriage in most farming communities is to engage family members for labour and to carry out other farming activities. Married people have more responsibilities to provide the household needs, hence the active involvement. The distribution of farmers by educational attainment indicates that $12.5 \%$ had no formal education, $4.2 \%$ had quranic education, $9.2 \%$ had adult education, $23.3 \%$ had primary education, $37.5 \%$ had secondary education which forms the majority, and $13.3 \%$ had tertiary education. It implies that majority of the farmers ( $87.5 \%)$ had one form of educational qualification. The level of education affects the type of decision farmers take in agricultural production and determines the level of opportunities available to improve livelihood strategies and managerial capacity in agricultural production (Sabo, 2011).The finding of this study agrees with the findings of Ogundari , Ojo \& Ajibefun (2006) who reported that education enhances productivity among farming households. Farmers were distributed according to household size as shown in Table 2. About 30\% of the household had $1-5$ members, $53.3 \%$ had 6-10 members, $12.5 \%$ had $11-15$ members and $4.2 \%$ had $16-20$ members. The mean household size was made up of seven members, which suggests there is labour readily available for the accomplishment of farm activities. The significance of household size in agriculture depends on the fact that the availability of labour for farm production, the total area cultivated to different crop enterprises, the amount of farm produce retained for domestic consumption, and the marketable surplus are all determined by the size of the farm household (Amaza \& Morris, 2009). However, large household size is associated with increased household consumption expenditure which reduces the money that could be used for production purposes (Harris-Fry, Azad \& Kuddus, 2015). This shows that $38.3 \%$ have a farming experience between $1-10$ years, $39.2 \%$ within $11-20$ years, $19.2 \%$ within $21-30$ years and $3.3 \%$ have 31 years and above. The mean farming experience was about 15 years. Farming experience is an important factor determining both the productivity and the production level in farming activities (Ajani, 2000). It is expected that the higher the farmers' experience in farming, the better will be the production capacity of the farmers. The majority of the farmers $(76.7 \%)$ were not participating in any cooperative society. 


\section{Rice Production Systems used by the Rice Farmers}

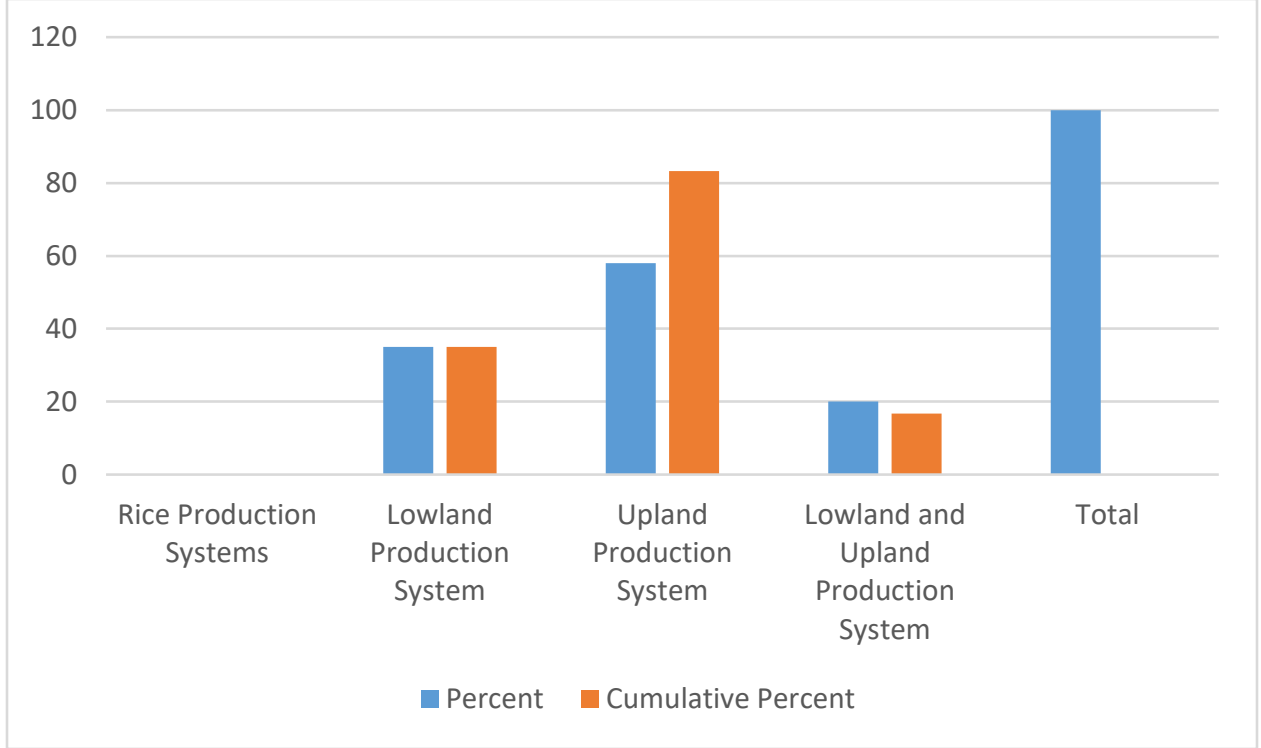

Figure 2. Distribution of Rice Farmers according to Rice Production Systems

Figure 2 presents the various production systems employed by the farmers for rice production. The figure shows that majority $(48.3 \%)$ of the rice farmers practiced the upland production system while $35 \%$ of the rice farmers practiced the lowland production system and $16.7 \%$ of the rice farmers used the combined (involving both the lowland and upland production systems). Many farmers practicing the upland rice production system might be due to nature of production in lowland system since it is labour intensive and hence, expensive. 
Table 3: Profitability of Rice Production Systems in the Study Area

\begin{tabular}{llll}
\hline Variable Costs & $\begin{array}{l}\text { Lowland } \\
\text { Average costha }\end{array}$ & $\begin{array}{l}\text { Upland } \\
\text { Average cost/ha }\end{array}$ & $\begin{array}{l}\text { Lowland and Upland } \\
\text { Average cost/ha }\end{array}$ \\
\hline Fertilizer & 17601.85 & 18101.91 & 21902.60 \\
Manure & 821.20 & 571.84 & 764.97 \\
Seeds & 4194.048 & 7399.38 & 7486.51 \\
Herbicide & 10589.03 & 10509.94 & 11416.00 \\
Insecticides & 4721.27 & 3177.13 & 2730.86 \\
Irrigation Water & 0.00 & 1215.29 & 997.06 \\
Other costs & 5529.28 & 3207.67 & 7528.14 \\
Hired Labour & 22301.62 & 36152.25 & 31194.14 \\
Family Labour & 31770.15 & 13760.95 & 10424.68 \\
Total Variable Cost & $101,186.12$ & $94,096.36$ & $94,444.96$ \\
Average Quantity of & 844.96 & 818.54 & 898.70 \\
Rice Produced(kg/ha) & & & \\
(Q) & & & \\
Average Price per Kg & 197.55 & 197.91 & 191.90 \\
of Rice (P) & & & \\
Total Revenue & $166,921.85$ & $161,997.25$ & $172,460.53$ \\
Gross Margin & $\mathbf{6 5 , 7 3 5 . 7 3}$ & $\mathbf{6 7 , 9 0 0 . 8 9}$ & $\mathbf{7 8 , 0 1 5 . 5 7}$ \\
\hline
\end{tabular}

\section{Source: Data Analysis, 2018}

Table 3 shows the gross margin analysis of rice production systems used by the farmers. The total variable cost for lowland rice production pattern was $\mathrm{A101,186.12}$ per hectare; the cost of upland rice production was $\mathrm{N} 94,096.36$ per hectare while the combined (lowland and upland) was A94,444.96 per hectare. This indicates that the lowland farmers seem to incur more production cost than the other two production groups. The average quantity of rice produced from lowland, upland and the combined production systems were $844.96 \mathrm{~kg} / \mathrm{ha}, 818.54 \mathrm{~kg} / \mathrm{ha}$ and $898.70 \mathrm{~kg} / \mathrm{ha}$ and average price per kilogram of rice was $197.55,197.91$ and 191.90 naira respectively with total revenue of $\mathrm{A} 166,921.85, \mathrm{~N} 161,997.25$ and $\mathrm{A172,460.53}$ respectively. The combined production system had the highest quantity of rice produced per hectare. This indicates that farmers obtain higher income when they combine the lowland and upland production systems. Calculating the gross margin for the three production systems, the gross margin per hectare of lowland rice 
production system was $\$ 65,735.73$, upland rice production system was $\$ 67,900.89$ per hectare, while the combined production system was $78,015.57$ per hectare. This shows that the combined production system had the highest gross margin than the lowland and upland rice production pattern, while the upland rice producers had more profit than the lowland rice producers.

Table 4: Factors Influencing Choice of Production Systems among Lowland and Upland Rice Farmers

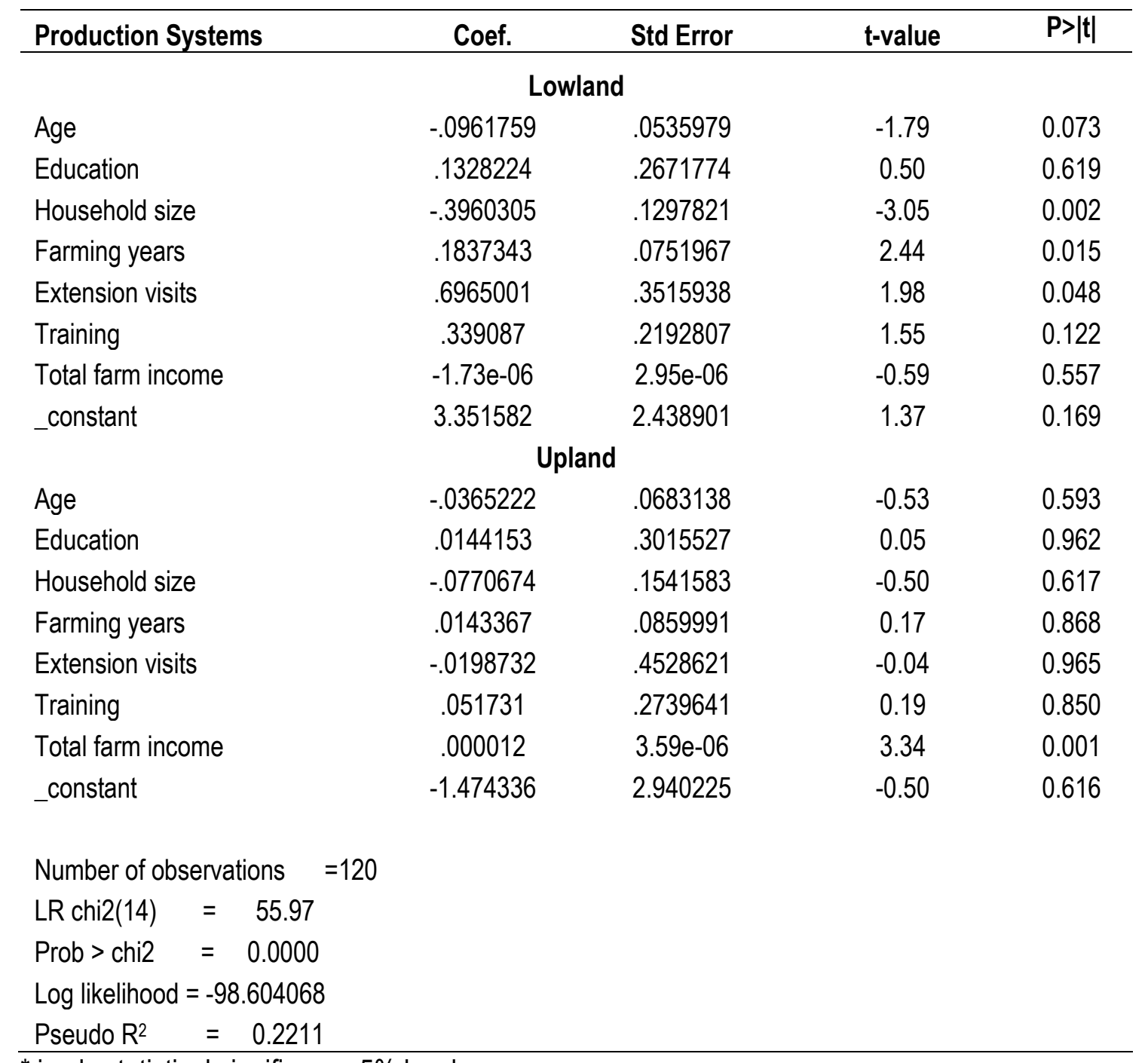

* imply statistical significance 5\% level,

Source: Data Analysis, 2018 
The results of the multinomial logit analysis showed the factors that influence the choice of the production system employed by rice farmers under lowland, upland and the combined (lowland and upland) rice production system in Table 4. The likelihood ratio Chi-square of 55.97 with a pvalue of 0.0000 is indicative of a good fit for the estimated model i.e. the null hypothesis that the all the independent variables are equal to zero, is rejected. Although the pseudo R-squared value (0.2211) was not high enough to confirm the explanatory variables that explain the variation in choosing each system of rice production, but the econometric analysis was able to report crucial estimates to explain the choice of rice production system. The effect coefficients were estimated with respect to the lowland rice production system (category 1) as the reference group. Therefore, the inference from the estimated coefficients for each choice category was made with reference to group 1. The factors that influenced the probability of the choice of the upland rice production system relative to lowland rice production system that were statistically significant include age, household size, farming years and extension visits; while the factor that influenced the choice of the combined rice production system relative to the lowland rice production systems that was statistically significant is farm income.

Age was significant at $10 \%$ level of significance implying that as age increases, farmers are less likely to use the upland rice production system in comparison to the lowland rice production system. Also, household size was statistically significant at $5 \%$ level indicating that as household size increases, farmers are less likely to choose the upland rice system in comparison to the lowland rice production system. Farming experience was also significant at $5 \%$ level indicating that as farming years increase, the upland rice system is more likely to be chosen by farmers in comparison to the lowland rice system. The result of decision to choose the upland rice production system shows that the coefficient of extension visitation is significant at 5\% to determine the farmers' likelihood of cultivating rice on upland relative to lowland. This means that as extension visits increases, farmers are more likely to choose the upland rice system in comparison to the lowland rice system. This estimate implies that large number $(69 \%)$ of farmers are more likely to produce rice on upland than lowland. Income was statistically significant at 5\% implying that as income increases, farmers are more likely to choose the combined rice production pattern relative to the lowland rice production system. 
Constraints Associated with Lowland and Rice Upland Production Systems

Table 5: Distribution of Rice Farmers According to Constraints Faced in Lowland and Upland Rice Production Systems

\begin{tabular}{|c|c|c|c|c|c|c|c|c|}
\hline Constraints & $\begin{array}{l}\text { Very } \\
\text { severe }\end{array}$ & Severe & $\begin{array}{l}\text { Mildly } \\
\text { severe }\end{array}$ & $\begin{array}{l}\text { Not } \\
\text { severe }\end{array}$ & NP & WS & MS & Rank \\
\hline Insufficient finance & $67(55.83)$ & $48(40.00)$ & $5(4.17)$ & $0(0.00)$ & $0(0.00)$ & 542 & 4.52 & $1 \mathrm{st}$ \\
\hline $\begin{array}{l}\text { Problem of pests } \\
\text { and diseases }\end{array}$ & $56(46.67)$ & $50(41.67)$ & $14(11.67)$ & $0(0.00)$ & $0(0.00)$ & 522 & 4.35 & $2^{\text {nd }}$ \\
\hline $\begin{array}{l}\text { High cost of } \\
\text { Agrochemicals }\end{array}$ & $39(32.50)$ & $70(58.33)$ & $9(7.50)$ & $2(1.67)$ & $0(0.00)$ & 506 & 4.22 & $3^{\text {rd }}$ \\
\hline $\begin{array}{l}\text { Unfavourable } \\
\text { climatic conditions }\end{array}$ & $30(25.00)$ & $60(50.00)$ & $16(13.33)$ & $12(10.00)$ & $2(1.67)$ & 461 & 3.87 & $4^{\text {th }}$ \\
\hline High cost of labour & $16(13.33)$ & $40(33.33)$ & $56(46.67)$ & $6(5.00)$ & $2(1.67)$ & 422 & 3.52 & $5^{\text {th }}$ \\
\hline $\begin{array}{l}\text { Inadequate access } \\
\text { with extension } \\
\text { agents }\end{array}$ & $4(3.33)$ & $48(40.00)$ & $45(37.50)$ & $19(15.83)$ & $4(3.33)$ & 389 & 3.24 & $6^{\text {th }}$ \\
\hline $\begin{array}{l}\text { Poor processing } \\
\text { and storage } \\
\text { facilities }\end{array}$ & $13(10.83)$ & $34(28.33)$ & $40(33.33)$ & $22(18.33)$ & $11(9.17)$ & 376 & 3.13 & $7^{\text {th }}$ \\
\hline $\begin{array}{l}\text { Poor transportation } \\
\text { system }\end{array}$ & $9(7.50)$ & $26(21.67)$ & $44(36.67)$ & $38(31.67)$ & $3(2.50)$ & 360 & 3.00 & $8^{\text {th }}$ \\
\hline $\begin{array}{l}\text { Farmland } \\
\text { inadequacy }\end{array}$ & $10(8.33)$ & $19(15.83)$ & $44(36.67)$ & $35(29.17)$ & $\begin{array}{l}12(10.0 \\
0)\end{array}$ & 340 & 2.83 & $9^{\text {th }}$ \\
\hline Inadequate seeds & $0(0.00)$ & $18(15.00)$ & $43(35.83)$ & $47(39.17)$ & $\begin{array}{l}12(10.0 \\
0)\end{array}$ & 307 & 2.56 & $10^{\text {th }}$ \\
\hline $\begin{array}{l}\text { Poor marketing } \\
\text { outlet }\end{array}$ & $1(0.83)$ & $8(6.67)$ & $38(31.67)$ & $46(38.33)$ & $\begin{array}{l}27(22.5 \\
0)\end{array}$ & 270 & 2.25 & $11^{\text {th }}$ \\
\hline
\end{tabular}

\section{Source: Data Analysis, 2018}

The results in Table 5 show various constraints associated with lowland and upland production systems in the study area. The constraints identified by rice farmers were ranked in order of severity using the mean score. The results show that insufficient finance was ranked $1^{\text {st }}$ among the constraints with a mean score of 4.52. This ranking showed that finance could hinder production of rice as a result of inability to purchase farming inputs. Problem of pests and diseases was ranked 
$2^{\text {nd }}(\mathrm{MS}=4.35)$. Pests and diseases pose great impediment on the production of rice. If this constraint is adequately handled, rice productivity could be higher in the area. High cost of agrochemicals was the $3^{\text {rd }}$ major constraint in the area $(M S=4.22)$, which could lead to underutilization by the farmers who majorly practice small scale farming. The constraint was followed by unfavourable climatic conditions as $4^{\text {th }}(M S=3.87)$. The ranking of this constraint have a negative effect on the production of rice in the area. Such conditions include erosion, flooding, drought and other unpredictable adverse climatic conditions that could reduce the yield of the total output.

High cost of labour is the $5^{\text {th }}$ constraint with a mean score of 3.52 . The high cost of labour may be attributed to the fact that rice production in the study area is labour-intensive and shortage of labour in relation to the demand as a result of competition for available labour raises the cost of labour. Inadequate access with extension agents was ranked $6^{\text {th }}(\mathrm{MS}=3.24)$. The result is conforming to the $47.5 \%$ of farmers without extension visit as shown in the analysis of the socio-economic variables. The $7^{\text {th }}$ constraint is poor processing and storage facilities with a mean score of 3.13 , followed by poor transportation system as the $8^{\text {th }}(\mathrm{MS}=3.00)$. Poor transportation system could lead to high marketing challenges resulting from damages in the process of conveying the produce. This often times leads to crop losses in addition to increase in total cost due to exorbitant transportation cost.

The last three challenges which are farmland inadequacy, inadequate seeds and poor marketing outlet were ranked $9^{\text {th }}, 10$ th and $11^{\text {th }}$ with a mean score of $2.83,2.56$ and 2.25 respectively. These constraints were considered not severe because their mean score was less than three (MS=3). Therefore there was less problem of farmland to cultivate rice. Seeds do not also pose much constraint as seeds from previous planting seasons were used in the current season, which was readily available. Marketing outlet was not a severe constraint because rice is an essential staple food consumed on a daily basis in the study area and also purchased by people outside the study area.

\section{CONCLUSION AND RECOMMENDATIONS}

The study compared the profitability of rice production systems of rice farmers in Kwara State and concludes that the choice of combined (lowland and upland) rice production system has the highest profitability. The combination of both rice production systems was found to result in the highest profitability and this has the potential of contributing to improved livelihoods of rice farmers. The study therefore recommends that training of farmers be supported by government and relevant stakeholders to enlighten farmers of the higher benefits of using the combined rice production system. It is essential that government increase the ratio of the number of extension agents to 
farmers so that the farmers will have more frequent contact with extension services. There should be arrangement for extension agents to be visiting at least twice a month, to ensure rice farmers benefit from the farm advisory services such as weather information, providing solutions to the challenges that farmers are associated with in rice production, which would increase their output. It is recommended that government should provide subsidy in inputs used for rice production such as fertilizer, agro-chemicals like herbicides and pesticides to prevent under-utilization due to high cost, and ensure small scale rice farmers procure them at minimal cost.

\section{REFERENCES}

Adeola R.G, Adebayo O.O and Oyelere G.O. (2008). Effects of the Federal Government Special Rice Programme on Rice Yields and Farmers' Income in Oyo State. International Journal of Agricultural Economics and Rural Development (IJAERD). 1 (1), 1-6.

Agricultural Transformation Agenda (ATA) (2010). Rice Transformation Project Proposal Report submitted to the Federal Ministry of Agriculture and Rural Development, Abuja Nigeria.

Ajani, O.I.Y. (2000). Resource Productivity in Food Farming in Northern area of Oyo State, Nigeria. Unpublished Ph.D. Thesis, Department of Agricultural Economics, University of Ibadan.

Akinwumi, A. and Djato, K.K. (1996). Farm Size, Relative Efficiency and Agrarian Policy in Cote d'Ivoire: Profit Function Analysis of Rice Farms. Agricultural Economics, 14(2): 93 - 102.

Amaza, P.S. and Maurice, D.C. (2005). Identification of Factors that Influence Technical Efficiency in Rice base Production Systems in Nigeria. A paper presented at workshop on policies and strategies for promoting rice production and food security in sub-Saharan Africa, Cotonon (Benin) $7^{\text {th }}$ - $^{\text {th }}$ November

Cadoni P., and Angelucci F., (2013). Analysis of incentives and disincentives for rice in Nigeria. Technical notes series, MAFAP, FAO, Rome.

Coalition for African Rice Development (2009). National Rice Development Strategy (Draft report). Federal Republic of Nigeria. Available online at $\mathrm{ftp}: / /$ ftp.fao.org/TC/TCA/SPFS/Presentations_Burkina_2009/Day3/Riz/Nigeria/PP_NRDS.pdf ebonyistate.gov.ng, Ebonyi State profile, accessed 17/04/17.

Department of Agriculture, Cooperation \& Farmer's Welfare (2017). Annual report, 2016-17, Ministry of agriculture \& farmer's welfare, Government of India.

Eze (2014). Availability and Use of Swamp Rice Production Technologies Among Farmers in Enugu state, Nigeria. Unpublished M.Sc Thesis submitted to the Department of Agricultural Extension, Faculty of Agriculture, University of Nigeria. 
Fakayode, S. B. (2009). Technical efficiency and factor productivity in upland and lowland rice production systems in Kwara State, Nigeria: Unpublished PhD thesis submitted in the Department of Agricultural Economics, University of llorin, Nigeria.

FAO, (2009). Food and Agricultural Organization Statistics. Food and Agricultural Organization (FAO). Retrieved from http://www.faostat.org/site/339/default.aspx. on November 20, 2012.

Federal Ministry of Agriculture and Rural Development (2012). Rice transformation project proposal. FMARD, Abuja.

Harris-Fry, H., Azad, K., and Kuddus, A., Shaha, S., Nahar, B., Hossen, M., Younes L., Costello A., and Fottrell E. (2015). Socio-economic determinants of household food security and women's dietary diversity in rural Bangladesh: a cross-sectional study. Journal of health, population, and nutrition, 33(2), 1-12.

International Fund for Agricultural Development (IFAD) (2012). Smallholders can feed the world. Rome. Retrieved from www.ifad.org/pub/viewpoint/index.htm (accessed 20 January 2013).

Imolehim, E. D. and Wada, A. C. (2000). Meeting the rice Production and Consumption Demands of Nigeria with Improved Technologies. International Rice Commission Newsletter, 49, 33-41

International Institute of Tropical Agriculture (1991). Sustainable Food Production in Sub-Saharan Africa. Institute of Tropical Agriculture, Ibadan.

International Fund for Agricultural Development (IFAD) (2009). Key elements for supporting the renewed focus on agricultural productivity and small-scale agricultural development in Nigeria. Insight No. 10.

IRRI (1995). World Rice Statistics. International Rice Research Institute. Metro Manila, Philippines, 34-42.

Ishaku U. G. (2013). Effects of President Umaru Musa Yar'adua's 7-point Agenda on Agricultural Development and Food Security in Nigeria. European Scientific Journal, 9(32), 448-462

Likert, R. (1932). A technique for the measurement of attitudes. Archives of Psychology. 22(140), 1-55.

Live Rice Index, USDA: Data for period 2014 to 2015. Live Rice Index, United Kingdom, 2016

Macauley, H. (2015). Cereal crops: Rice, Maize, Millet, Sorghum, Wheat. Background paper at Feeding Africa Conference, 21-23 October, 2015, Abdou Diouf International Conference Center, Dakar, Senegal. www.afdb.org/fileadmin/upload..._sorghum_wheat.pdf'

National Bureau of Statistics/ Federal Ministry of Agriculture and Rural Development, Collaborative survey on National Agriculture Sample Survey (NASS) 2019 
National Population Commission (NPC) [Nigeria] and ICF Macro (2009). Nigeria Demographic and Health Survey 2008. National Population Commission and ICF Macro, Abuja, Nigeria.

Chidiebere-Mark, N., Ohajianya, D., Obasi, P., and Onyeagocha, S. (2019). Profitability of rice production in different production systems in Ebonyi State, Nigeria. Open Agriculture 4, 237-246.

Nosiru, O.M.O., Rahji, M.A.Y., Ikpi, A.E. and Adenegan, K.O. (2014). Scale Efficiency and Determinants of productivity of New Rice for Africa (NERICA) farmers in Kaduna state, Nigeria. Agrosearch, 14 (2), 113-128

Odoemenem I.U and Inakwu J.A, (2011). Economic Analysis of Rice Production in Cross River State. Journal of Development and Agricultural Economics, 3(9), 469-474.

Ogundari, K., Ojo, S. O. and Ajibefun, I. A. (2006). Economies of Scale and Cost Efficiency in Small Scale Maize production: Empirical Evidence from Nigeria. Journal of Social Sciences, 13(2), 131 - 136.

Okoruwa, V. O, Akindeinde A. O., and Salimonu K. K. (2009). Relative Economic Efficiency of Farms in Rice Production. A Profit Function Approach in North Central Nigeria. Tropical and Subtropical Agroecosystems, 10(17), 279-286.

Onumadu F.N. and Osahon E.E. (2014). Socio-Economic Determinants of Adoption of Improved Rice Technology by Farmers In Ayamelum Local Government Area of Anambra State, Nigeria. International Journal of Scientific and Technology Research, 3(1), 308-314.

Oyinbo O., Damisa M.A., and Rekwot G.Z. (2013). Growth trend of rice demand and supply in Nigeria: Opportunity for youth and women empowerment. Russian Journal of Agricultural and Socio-economic Sciences, 4(6), 31-34

Stryker D.J., (2010). Developing competitive rice value chains. Panel discussion on second Africa Rice Congress, "Innovation and Partnerships to realize Africa's Rice Potential", Bamako, Mali, 22-26 March, 2010. 